\title{
PELATIHAN PEMBUATAN PERANGKAT CBT (Computer Based Test) UNTUK MEMPERSIAPKAN SEKOLAH SIAGA BENCANA
}

\author{
1) Dini Nurmalasari, ${ }^{2)}$ Mardhian Fadhly, ${ }^{3)}$ Wenda Novayanti, ${ }^{4)}$ Yuli Fitrisia \\ 1,2,3,4)Program Studi Teknik Komputer, Jurusan Teknologi Informasi, Politeknik Caltex Riau \\ 1,2,3,4) Jl. Umban sari (Patin) No.1 Rumbai, Pekanbaru - Riau - Indonesia \\ E-mail :anggy@pcr.ac.id,indah@pcr.ac.id,istianah@pcr.ac.id
}

\begin{abstract}
ABSTRAK
Proses belajar mengajar antara siswa dengan guru meliputi kegiatan tatap muka dan evaluasi dalam bentuk ujian. Pada kondisi tertentu seperti kejadian bencana alam kabut asap atau wabah penyakit, proses belajar mengajar tidak dapat dilakukan secara langsung. Salah satu alternatif pengganti kegiatan tatap muka dalam proses belajar mengajar adalah SPADA (Sistem Pembelajaran Daring), yang sudah diresmikan secara nasional pada tahun 2014. Sistem daring ini memungkinkan siswa dan guru berada ditempat yang berbeda namun dapat melaksanakan pembelajaran secara online. Selain pembelajaran online, ujian atau evaluasi juga dapat dilakukan secara daring. Terdapat banyak aplikasi gratis yang dapat dimanfaatkan untuk membuat sistem ujian online atau dikenal dengan nama CBT. Namun tidak semua guru memahami dan mengetahui cara menggunakan dan membuat aplikasi CBT tersebut. Pada kegiatan Pengabdian kepada Masyarakat kali ini dosen di Program Studi Teknik Komputer memberikan pelatihan dan workshop cara menggunakan dan membuat aplikasi CBT dengan cara online melalui aplikasi streaming Zoom Cloud. Pada kegiatan workshop yang dilaksanakan selama dua hari ini diikuti oleh kurang lebih 225 peserta guru SMA dan sederajat yang berasal dari berbagai kota di Riau dan sebagian kecil dari luar Riau dan luar Sumatera.
\end{abstract}

Kata Kunci: google classroom, aplikasi CBT, Bencana Alam

\begin{abstract}
Learning process between students and teachers includes face-to-face activities and evaluation in the form of exams. In certain conditions, such as the natural disasters of haze or disease outbreaks, the teaching and learning process cannot be done directly. One alternative to face-to-face activities in the teaching and learning process is SPADA (Online Learning System), which was inaugurated nationally in 2014. This online system allows students and teachers to be in different places but can carry out online learning. Apart from online learning, exams or evaluations can also be done online. There are many free applications that can be used to create an online exam system, known as CBT. However, not all teachers understand and know how to use and make the CBT application. In this Community Service activity, lecturers in the Computer Engineering Study Program provide training and workshops on how to use and create CBT applications online through the Zoom Cloud streaming application. The workshop which was held for two days was attended by approximately 225 participants from high school and equivalent teachers who came from various cities in Riau and a small part from outside Riau and outside Sumatra.
\end{abstract}

Keyword: Google Classroom, CBT Application, Natural disasters

\section{PENDAHULUAN}

\section{Latar Belakang}

Sistem Pembelajaran Daring (SPADA) telah dikembangkan dan diresmikan secara nasional sejak tahun 2014. Program SPADA ini merupakan salah satu implementasi dari Undang-Undang Republik Indonesia Nomor 20 Tahun 2003, dan Peraturan Menteri Pendidikan dan Kebudayaan Nomor 109 Tahun 2013 tentang Penyelenggaraan Pendidikan Jarak Jauh [1]. Salah satu tujuan dari program SPADA ini adalah untuk meningkatkan pemerataan akses terhadap pembelajaran yang bermutu. Pembelajaran ini memungkinkan siswa di sekolah tertentu dapat mengikuti pembelajaran materi tertentu dari sekolah lain dan hasil belajarnya dapat diakui sama oleh sekolah tersebu 
Pada kondisi tertentu seperti bencana alam, semisal bencana kabut asap serta wabah virus seperti saat ini, pembelajaran Daring sangat diperlukan. Dimana fungsinya bukan lagi mengakses materi dari sekolah lain melainkan pertemuan tatap muka antara guru dan murid dapat dialihkan secara daring. Guru dan murid yang pada saat terjadi bencana dihimbau untuk tidak keluar rumah, namun tetap harus melaksanakan kegiatan pembelajaran, maka dapat dilakukan secara daring.

Tidak hanya pembelajaran tatap muka yang dapat dialihkan menjadi pembelajaran secara daring, namun ujian pun dilakukan secara daring. Aplikasi ujian online adalah sebuah aplikasi yang dipakai untuk menyelenggarakan ujian dengan memanfaatkan teknologi komputer, smartphone dan lain-lain. Model ujian ini lebih dikenal dengan nama Computer Based Test (CBT) atau Computer Assisted Test (CAT) [2]. Semua tahapan ujian dilaksanakan melalui komputer, mulai dari proses pembuatan soal, pengaturan kelas, pengaturan pengguna yang akan mengikuti ujian, pengaturan guru, pelaksanaan ujian sampai dengan tahapan penilaian. Beberapa aplikasi online yang dapat dimanfaatkan untuk ujian online diantaranya adalah google classroom yang dapat dikolaborasikan dengan drive dan google form, Zenius, FlyExam, Quizizz, Kahoot, Aila, ZYA CBT dan lain sebagainya[7].

Salah satu aplikasi yang mudah digunakan, terintegrasi dengan email dan tempat penyimpanan data / drive adalah google classroom. Fitur dari google classroom sangat banyak sekali, mulai dari pembuatan materi pembelajaran, pembuatan bank soal, pelaksanaan ujian, pengaturan peserta ujian, pengaturan jadwal ujian, penilaian sampai dengan penyimpanan soal yang tersimpan dengan baik [4] Disamping itu google classroom juga memungkinkan kita melakukan kolaborasi dengan aplikasi lainnya melalui google link atau fitur lainnya.

Namun berdasarkan hasil wawancara yang dilakukan kepada beberapa guru, tidak semua guru siap dengan sistem daring, terutama pelaksanaan ujiannya (CBT). Masih terdapat guru yang belum terbiasa menggunakan aplikasi-aplikasi tersebut, sehingga pada saat kejadian luar biasa seperti bencana alam ini, terdapat guru yang kerepotan karena gagap teknologi. Sehingga proses belajar mengajar tidak dapat sepenuhnya dilakukan. Hal ini perlu ditangani dengan segera, salah satunya dengan memberikan pelatihan penggunaan aplikasi CBT kepada guru-guru di daerah Riau khususnya Pekanbaru.

Berdasarkan hasil identifikasi kebutuhan mitra yang dilakukan melalui proses wawancara dan pengamatan secara langsung, maka permasalahan mitra secara khusus adalah sebagai berikut

1. Kurangnya pemahaman guru pendidik dalam menggunakan aplikasi ujian online (CBT)

2. Kesulitan dalam pemberian evaluasi ketika terjadi bencana yang mengharuskan siswa tidak masuk sekolah.

3. Adanya siswa-siswa dengan kebutuhan khusus yang mengharuskan pelaksanaan evaluasi secara online.

\section{METODE PELAKSANAAN}

Pelaksanaan pelatihan dan workshop pembuatan perangkat CBT ini dilakukan dalam bentuk workshop dengan kerangka kerja pada gambar 1 sebagai berikut [8]: 


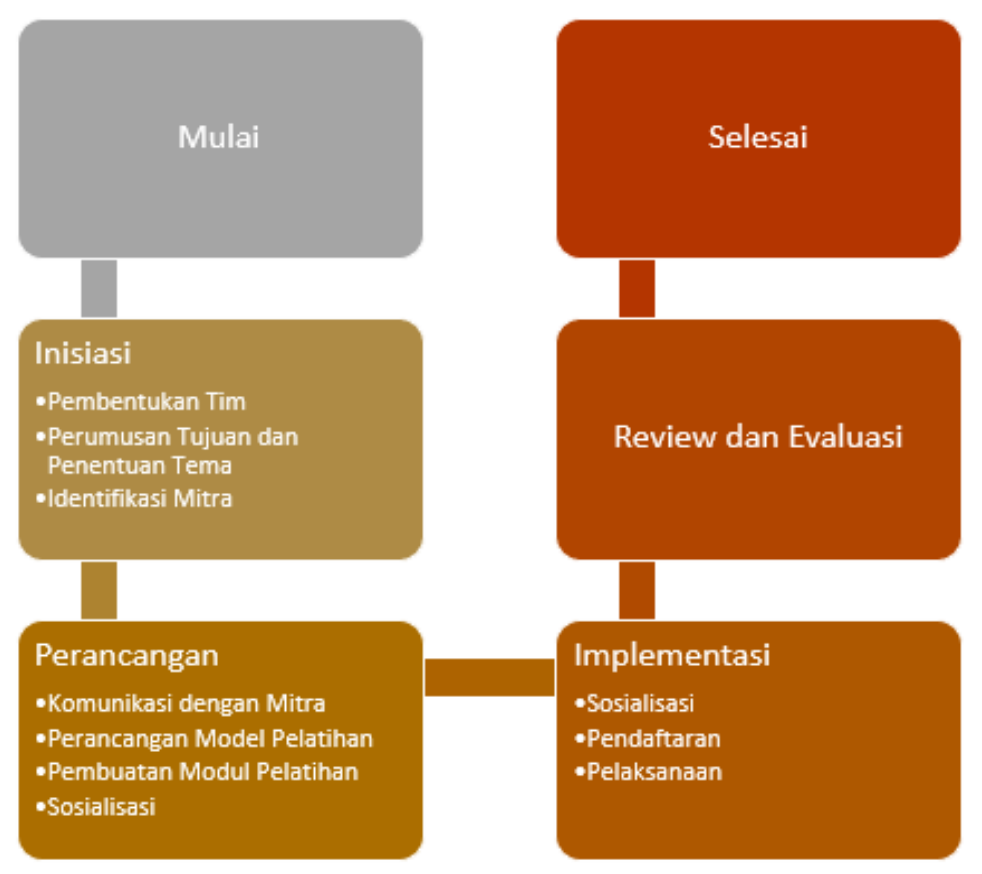

\section{Gambar 1. Kerangka Kerja Kegiatan Pengabdian}

Metodologi pelaksanaan kegiatan pengabdian dilakukan dengan tahapan sebagai berikut:

1. Tahapan inisiasi meliputi pembuatan tim, perumusan tujuan serta penentuan tema. setelah tim terbentuk, dilakukan beberapa kali pertemuan untuk mendiskusikan permasalahan mitra, tujuan kegiatan pengabdian, menentukan bentuk kegiatan serta penentuan bentuk luaran. Dalam tahapan ini akan menghasilkan proposal kegiatan untuk tahapan berikutnya, yakni persiapan teknis.

2. Tahapan perancangan, meliputi komunikasi dengan mitra untuk mendiskusikan format kegiatan dan tujuan kegiatan, setelah itu tim membuat perancangan model pelatihan yang disesuaikan dengan karakteristik mitra. Hasil dari tahapan ini adalah modul pelatihan yang digunakan oleh peserta pelatihan, dengan rincian modul :

a. Modul cara membuat dan mengelola kelas menggunakan google classroom

b. Modul cara membuat jadwal belajar menggunakan google classroom

c. Modul cara menggunakan fitur transfer class dengan google classroom

d. Modul cara menggunakan google meet dan mengintegrasikannya dengan aplikasi lain seperti google whiteboard, google attendance dan quizzes.
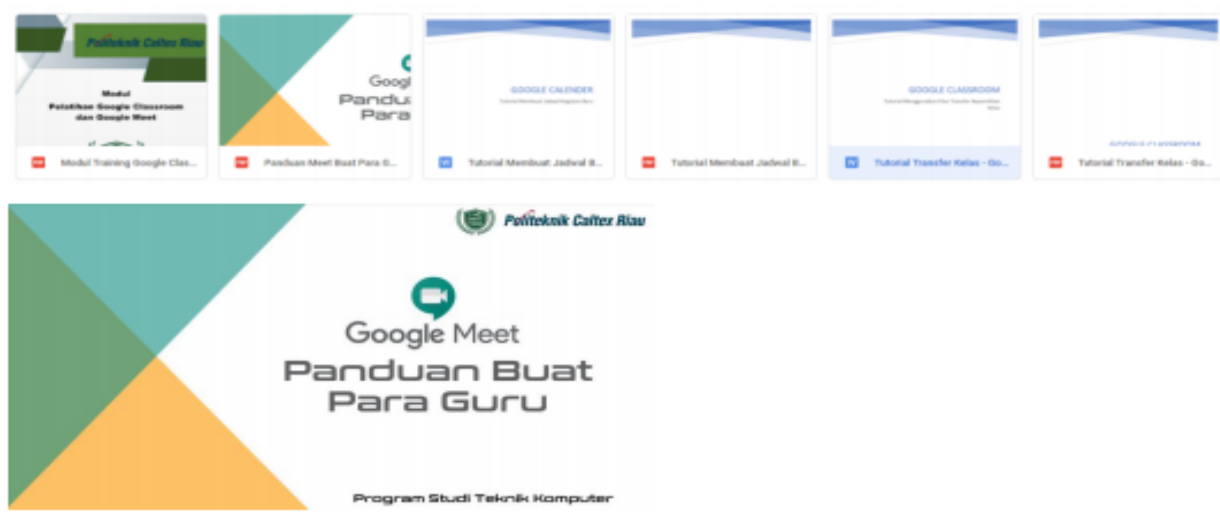

Gambar 2. Modul Pelatihan 
3. Tahapan implementasi dimulai dengan melakukan sosialisasi melalui media sosial, membuka pendaftaran dan melaksanakan kegiatan seperti yang sudah direncanakan sebelumnya. Pendaftaran Peserta di-publish secara online sebelum tanggal pelaksanaan, dan peserta pelatihan terbuka untuk umum namun terbatas dengan target spesifikasi peserta yang telah ditentukan sebelumnya. Pelaksanaan Kegiatan Pelaksanaan kegiatan secara umum akan dilakukan dalam workshop sehari dengan detail sebagai berikut :

Tanggal : 08 - 09 Juli 2020

Waktu : 09:00 - Selesai

Lokasi : Daring, via Google Meet

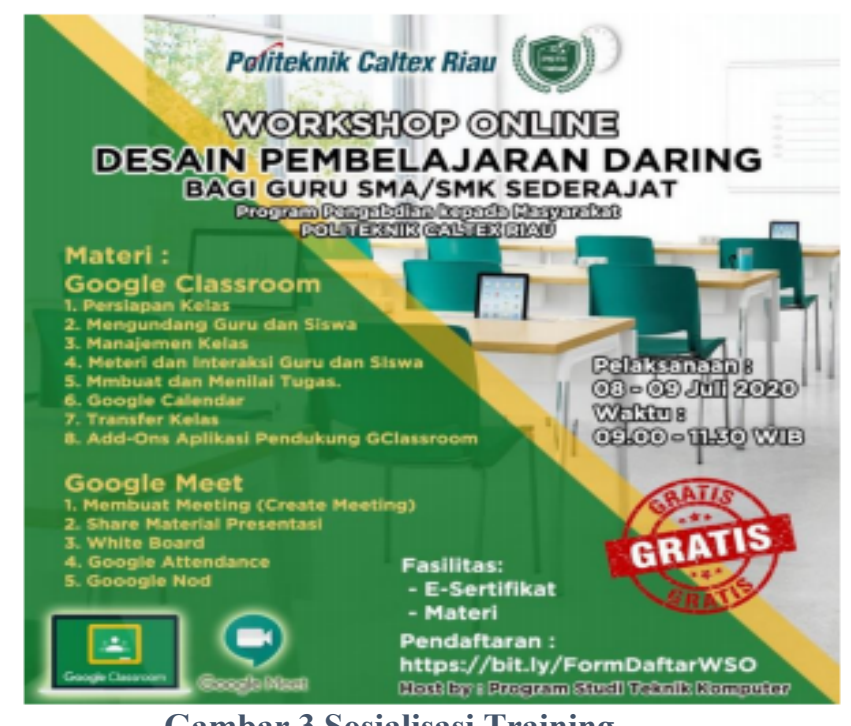

Gambar 3 Sosialisasi Training

Peserta yang mendaftar pada pelatihan dan workshop ini berjumlah 454 yang terdiri dari guru-guru yang berasal dari Pekanbaru, Dumai, Tanah Putih, Duri, Payakumbuh, Kampar, Batu Hampar, Bengkalis, Bangko, Padang, Solok, Pangkalan Kerinci, Bangkinang, Taluk Kuantan, Gasib, Tembilahan, dan dari luar daerah Riau yaitu Banten dan Bandung.

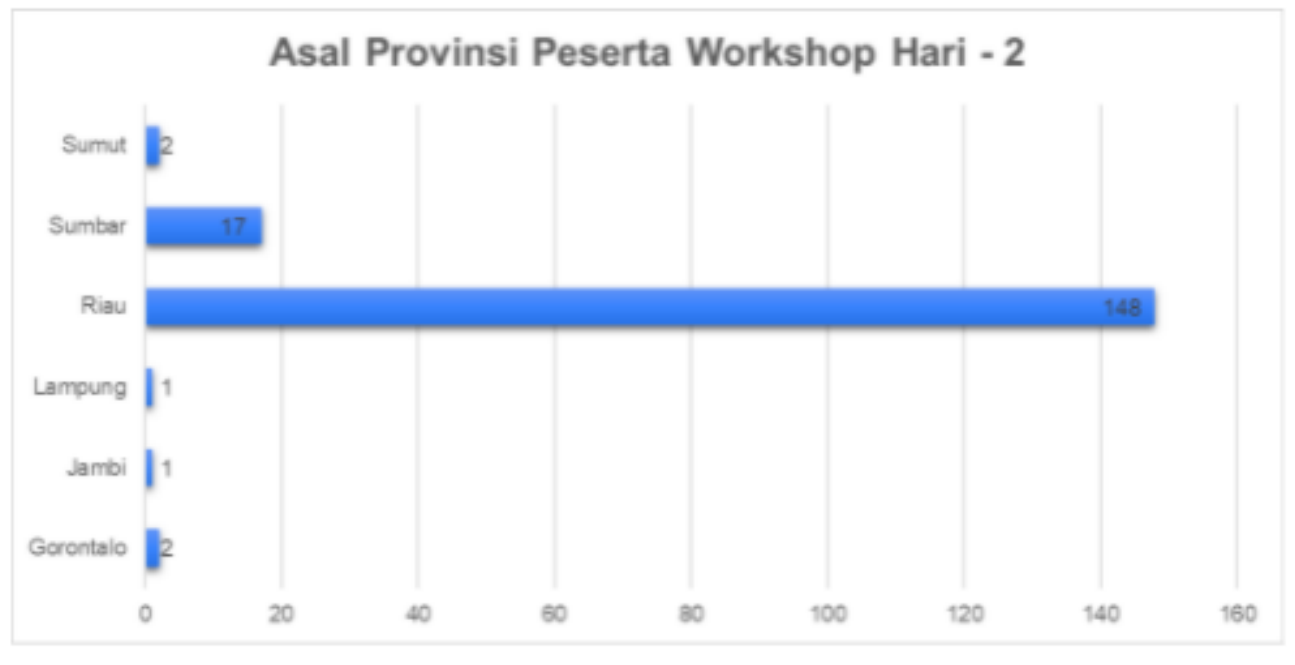

Gambar 4. Asal Peserta

4. Evaluasi dan Review dilakukan dengan cara meminta feedback dan masukan kepada semua peserta melalui google form. 

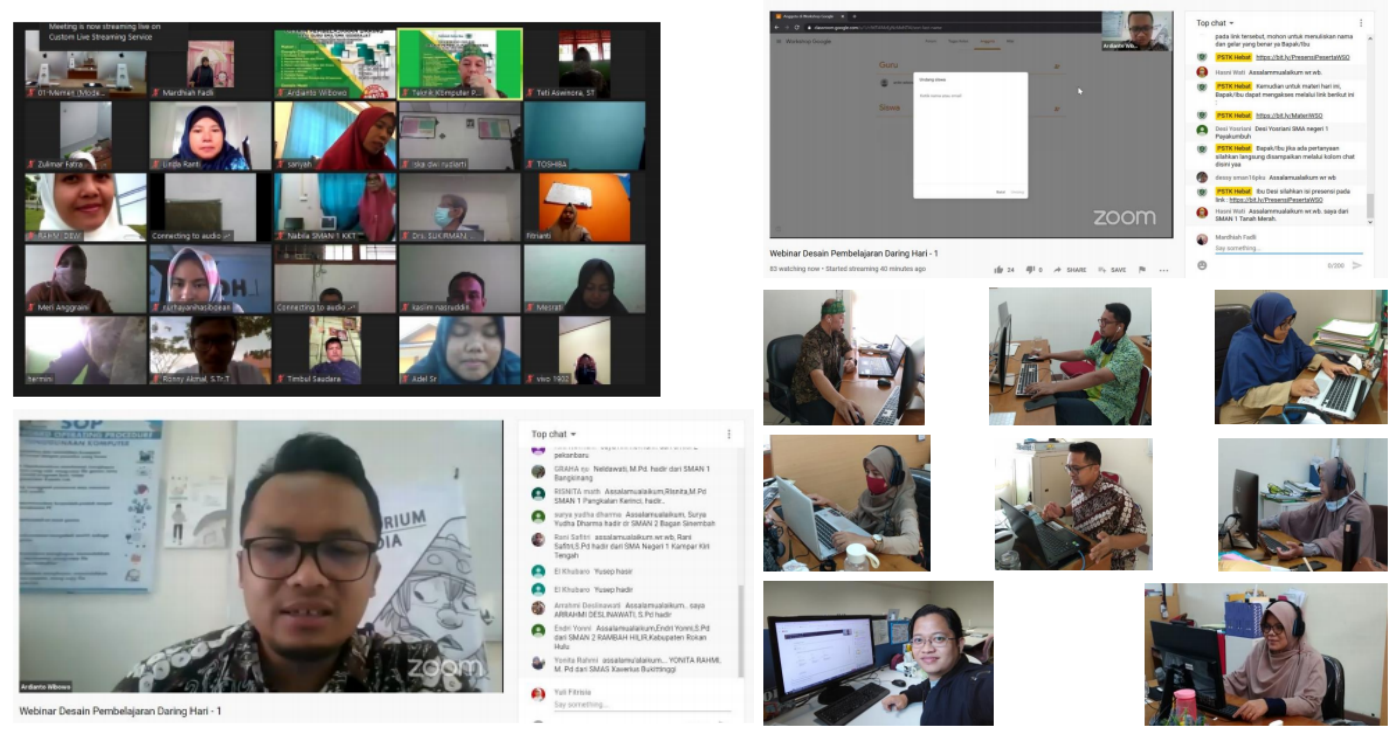

Gambar 5. Dokumentasi Kegiatan Hari H

\section{HASIL}

Hasil dari kegiatan ini diharapkan seluruh peserta dapat membuat media ajar dan media evaluasi dengan menggunakan teknologi yang telah disampaikan. Untuk melihat dampak dari kegiatan ini, tim melakukan monitoring dan evaluasi kepada semua peserta dalam kurun waktu 3-4 bulan setelah kegiatan dilakukan. Pada bulan Oktober dan November 2020 dilakukan review kepada seluruh peserta pelatihan melalui pengisian kuesioner yang diberikan melalui email. Evaluasi dilakukan melalui beberapa pertanyaan sebagai berikut :

1. Ketersampaian materi kepada peserta

2. Kebermanfaatan kegiatan

3. Kemauan menerapkan dan mengimplementasikan Google Classroom dan Google Meet di sekolah masing-masing

4. Kendala-kendala yang dihadapi

5. Keinginan Training kedepannya.

Adapun bentuk pertanyaan yang disampaikan adalah sebagai berikut :

P1: Materi Workshop yang disampaikan sudah sesuai dengan harapan Bapak/Ibu.

P2: Proses penyampaian dapat dipahami dengan baik.

P3: Materi/Modul yang diberikan sangat membantu dalam mempersiapkan proses pembelajaran pada masa daring saat ini.

P4: Kegiatan ini memberikan tambahan wawasan kepada Bapak/ibu terkait pembelajaran daring.

Pertanyaan yang diberikan terdiri dari 4 pertanyaan mengenai Google Classroom dan 4 pertanyaan mengenai Google Meet. Hasil dari proses review tersebut cukup baik, seperti terlihat pada gambar 5 berikut ini : 


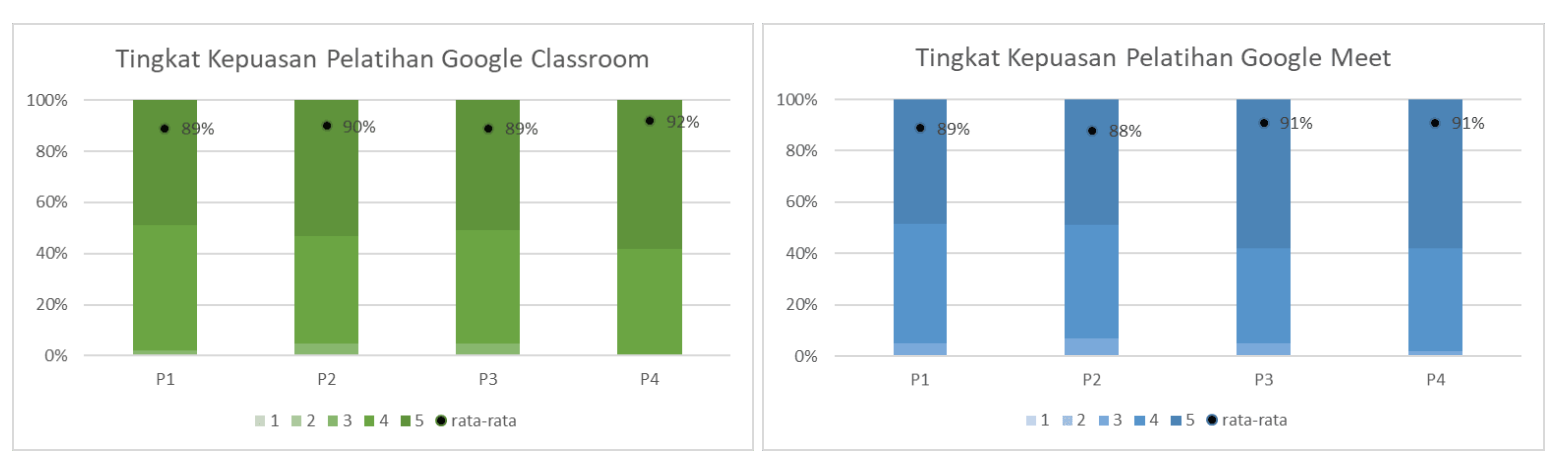

Gambar 6. Tingkat Kepuasan Peserta Pelatihan

Berdasarkan hasil tersebut dapat dilihat bahwa tingkat kepuasan peserta terhadap materi yang diberikan, proses penyampaian, modul diberikan dan tambahan wawasan dan pengetahuan buat peserta adalah sangat baik dan Program ini menjadi penguatan buat mereka dalam menjalani proses belajar mengajar di sekolah mereka masing-masing. Pada materi pelatihan telah disampaikan bahwa Google Classroom dan Google Meet dapat diintegrasikan untuk pelaksanaan CBT yang lebih termonitor dengan baik, sehingga pemahaman terhadap materi Google Classroom dan Google Meet sangatlah penting.

Survey berikutnya dilakukan untuk mendapatkan umpan balik mengenai tingkat kepercayaan diri peserta terhadap pemahaman menggunakan Google Classroom dan Google Meet, yang dapat dilihat pada gambar 6 berikut ini :
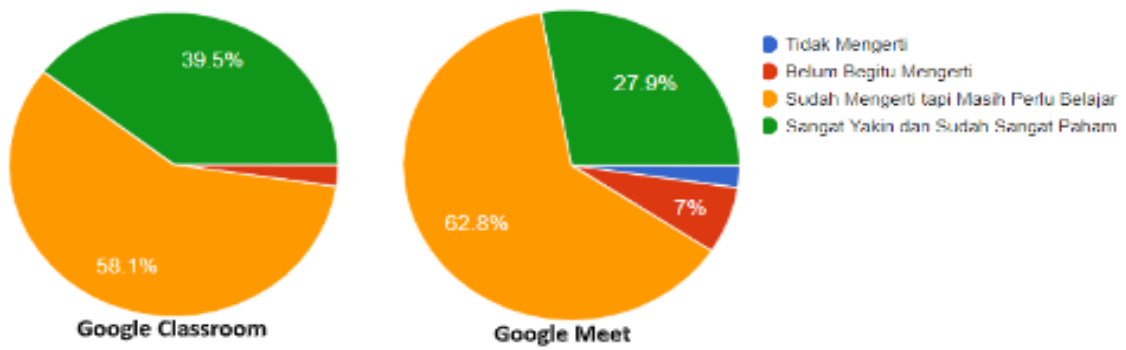

Gambar 7. Tingkap Pemahaman Materi

Pemahaman materi penggunaan Google Classroom dan Google Meet oleh peserta setelah selesai mengikuti Workshop ini sudah cukup baik berada di lebih dari 90\% peserta. Namun jika dilihat presentasi yang belum mengerti, terlihat lebih banyak yang belum mengerti penggunaan aplikasi Google Meet, hal ini disebabkan karena media streaming yang sedang berkembang saat ini terdapat beberapa pilihan alternatif.
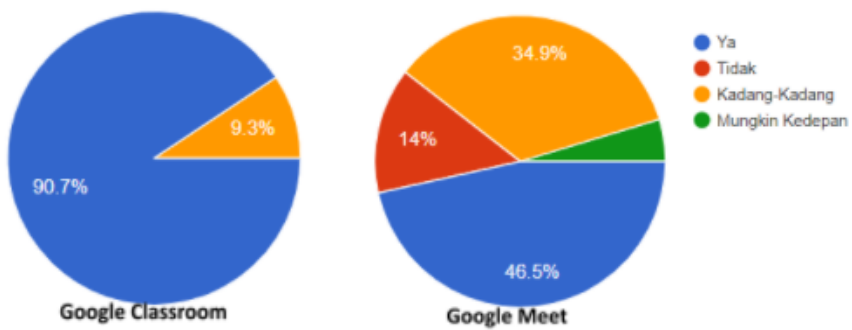

Gambar 8. Tingkat penggunaan Google Classroom dan Meet oleh peserta 
Survey juga dilakukan untuk mengetahui implementasi penggunaan Google Classroom dan Google Meet oleh peserta setelah selesai mengikuti Workshop. Hasil yang didapatkan 90.7\% peserta berkelanjutan menggunakan Google Classroom, sementata 46.5\% peserta menggunakan Google Meet pada proses pembelajaran dan evaluasinya dan 34.9\% kadang-kadang menggunakannya.

\section{KESIMPULAN}

Kegiatan pengabdian yang telah dilakukan kepada Guru-Guru SMA/SMK Sederajat untuk mendesain perangkat ajar dan perangkat evaluasi (CBT) dengan menggunakan Google Classroom dan Google Meet memberikan dampak yang luar biasa bagi Guru-Guru. Berdasarkan hasil kuesioner yang telah dilakukan kepada peserta sebanyak 43 responden menyampaikan bahwa:

1. Program pemberian pelatihan pembuatan aplikasi CBT bagi Guru-Guru SMA/SMK Sederajat dalam proses mendesain model evaluasi Daring berjalan dengan baik dan lancar, terlihat dari Antusias Guru-Guru dalam mengikuti kegiatan ini, terlihat dengan banyaknya jumlah pendaftar yang ingin mengikuti kegiatan ini.

2. Materi yang disampaikan sesuai dengan harapan para guru, modul dan kit yang diberikan sangat membantu dan kegiatan ini memberikan tambahan wawasan bagi para guru untuk mendesain proses pembelajaran di sekolah masing-masing, terbukti dari hasil kuesioner nilai diperoleh mencapai 85\% kepuasan peserta.

3. Google Classroom dapat dijadikan sebagai salah satu alternatif media evaluasi daring dengan beberapa fitur nya yang lengkap diantaranya integrasi dengan aplikasi lain, google form dan google meet untuk melaksanakan evaluasi secara daring.

\section{DAFTAR PUSTAKA}

[1] Andriani. (2015). Sistem Pembelajaran Berbasis Teknologi Informasi dan Komunikasi. Jurnal Solusi Budaya: Media Komunikasi Ilmu Ilmu Sosial dan Budaya, vol. 12, no. 1: 128- 150.

[2] Darmawan. (2019). Penggunaan Aplikasi Google Classroom dalam Upaya Meningkatkan Hasil Belajar Matematika pada Siswa Kelas X SMA Jurusan IPS. Skripsi, Fakultas Keguruan dan Ilmu Pendidikan. Universitas Muhammadiyah Surakarta: 1-15.

[3] Hasanudin, dkk. (2018). Optimalisasi Pemanfaatan Google Classroom sebagai Media Pembelajaran di SMK Negeri 1 Bakinang. Jurnal Pendidikan Untuk Mu Negeri, vol. 2, no. 1: 17-20.

(http://ejurnal.umri.ac.id/index.php/Pengabdia nUMRI/article/view/361/352)

[4] Iftakhar. (2016). Google Classroom: What Works and How?. Jurnal of Education and Social Sciences, vol. 3, no. 1: 12-18.

[5] Hamka, Vilmala. (2019). Pengembangan Perangkat Pembelajaran Blended Learning Melalui Aplikasi Google Classroom Untuk Peningkatan Kemandirian Belajar Mahasiswa. Journal of Education Informatic Technology and Science, vol. 1, no. 2: 145- 154. (http://ejurnal.umri.ac.id/index.php/JeITS/art icle/view/1439/858)

[6] Suryadi, Andri. "Perancangan Aplikasi Tes Berbasis Komputer (Cbt) Menggunakan Pendekatan Terstruktur Untuk Penerimaan Mahasiswa Baru Di Perguruan Tinggi." 
JURNAL PETIK 1.1 (2015): 68-81.

[7] Suhendri, Sabri, dkk. "Pelatihan Pembelajaran Jarak Jauh (Pjj) Pada Masa Pandemi Covid19 Bagi Guru Sekolah Dasar Islam Terpadu (Sdit) Dod Medan" Jurnal Pengabdian Kepada Masyarakat(10.24114) Vol 27, no 12021

[8] Malalina, Rika Firma Yenni. "Pelatihan Google Classroom Untuk Mengoptimalisasi Proses Pembelajaran Di Fkip Universitas Tamansiswa Palembang" Jurnal Cemerlang: Pengabdian Pada Masyarakat Vol 1, No 12018 